\title{
Diversity of Arbuscular Mycorrhizal Fungi Associated with Smilax perfoliata Lour
}

\author{
Sufian A. Tapadar ${ }^{1 *}$, Himadri Kalita ${ }^{1}$, Afrida Hussain ${ }^{2,3}$, Daimalu Baro ${ }^{2}$ and D.K. Jha ${ }^{2}$ \\ ${ }^{1}$ Department of Botany, University of Science and Technology, Meghalaya, India \\ ${ }^{2}$ Department of Botany, Gauhati University, Assam, India \\ ${ }^{3}$ Department of Botany, Cotton College, Guwahati, Assam, India \\ *Corresponding author
}

A B S T R A C T

Smilax perfoliata Lour is a traditionally used medicinal plant by many tribes of North-east India. There is no report of AM fungal diversity of this medicinally important plant. The present study is aimed to assess the AM fungal diversity in Smilax perfoliata Lour. Soil

Keywords

Smilax perfoliata

Lour; AM fungi,

Root colonization,

Spore density,

Monosporic

culture.

Article Info

Accepted:

30 June 2017

Available Online:

10 July 2017 sample was collected from Manas National Park, Assam, India. The studied soil sample was found slightly alkaline in nature $(\mathrm{pH}: 7.8)$. The percent root colonization was recorded $82.98 \pm 1.01 \%$. AM Fungal spore density in the soil sample of Smilax perfoliata Lour was 147 spores $20 \mathrm{gm}^{-1}$ and species richness was 23. Rhizophagus fasciculatus and Glomus citricola showed highest relative abundance (6.45\%). Eighteen AM fungal taxa were recorded from trap culture. Glomus citricola showed highest relative abundance (12.84\%) in trap culture. Nine AM fungal taxa viz. Acaulospora denticulata, Glomus sp.4 G. pellucidum, G. tortuosum, Rhizophagus diaphanum, Ambispora fecundispora, Gigaspora rosea and Sclerocystis sp.1. were recorded in trap culture that was not observed in original soil sample. Glomus was the dominant genus during the present investigation. The monocultures of Rhizophagus fasciculatus, Glomus aggregatum, G. citricola, Funneliformis geosporum and Claroideoglomus etunicatum were successfully raised. The root colonization and spore density were highest in monoculture of $F$. geosporum and lowest in case of $C$. etunicatum. The present investigation provides knowledge and understanding about the presence and diversity of AM fungi in Smilax perfoliata Lour. This also provides good possibilities for further studies and utilization of AM fungi.

\section{Introduction}

Mycorrhiza is a mutualistic symbiotic relationship between the root system of higher plants and fungal hyphae. The fungal network increases the capacity of plant to absorb more water and nutrients. This process helps in growth and favours rapid development of roots and plants. Arbuscular mycorrhiza (AM) is the most ancient type of mycorrhizal association between land plants and fungi of the phylum Glomeromycota (Tapadar et al., 2016b; Schüßler et al., 2001). AM fungi colonize the terrestrial plants of most ecosystem and forms functional links between soil and plants (Smith and Read, 2008). They facilitate inter plant transfer of nutrients, modify plant water relations and thereby improve stability of plant community (Smith and Read, 1997). It also plays an important role in stability of soil structure and water retention by the production of sticky 
proteinaceous substances known as glomalin (Bedini et al., 2009). The endosymbiotic AM Fungi develop some special structures called vesicles and arbuscules, within the root cells. Vesicles are thick-walled, spherical to oval shaped structures born on the tip of the hyphae for storage purpose either in intercellular spaces or in the cortical cells of the root. Arbuscules are the dichotomously branched structures, which are formed inside the parenchyma cells for nutrient exchange with the plant (Gianinazzi-Pearson, 1996). Arbuscles are the sites of exchange for phosphorus, carbon, water and other nutrients. The populations of AM Fungi is greatest in plant communities with high diversity such as tropical rainforests and temperate grasslands where they have many potential host plants and can take advantage of their ability to colonize a broad host range.

There have been many research works carried out throughout the world to understand the interactions between AM Fungi and plants ( $\mathrm{Li}$ et al., 2013; Stein et. al, 2009; van der Heijden and Horton, 2009, Jordan and Huerd, 2008), and to understand the functionality of AM fungi as influenced by variations in environmental conditions, especially in their natural environment (Likar et al., 2009). AM Fungi shows different responses on root colonization intensity and spore population depending on the host species or environmental factors (Likar et.al, 2008; Li et al., 2005). Reports suggest that AM Fungi contribute to plant diversity, community structure and ecosystem sustainability (Grime et al., 1987; van der Heijden et al., 2008). In different medicinal plants, the occurrence of AM Fungi have been studied previously by many researchers (Tapadar et al., 2016b; Muthukumar and Udaiyan, 2000; Selvoraj, Murugan and Bhaskaran, 2001; Rani and Bhaduria, 2001). Discoveries of medicinal research lead to know that the plant contained abundant of principle active metabolites which can be used to cure diseases. These plants have good application in herbal, pharmaceutical, agricultural sectors. AM Fungi affects secondary metabolism and active ingredient production of plants (Lingua et al., 2013).

Smilax perfoliata Lour is also a traditionally used medicinal plant by many tribes of Northeast India. Smilax is a large genus belongs to Smilacaceae family. The genus includes both deciduous and evergreen species. It is distributed in tropical, subtropical and temperate regions of the world. Stem and root of Smilax perfoliata Lour is used as anticancer, anti-dysenteric and in urinary complaints (Pawer et al., 2011). It is also used as a blood purifier (Buragohain, 2011). Zhasa et al., (2015) reported ethnomedicinal use of Leaves and roots of Smilax perfoliata as demulcent, depurative, diaphoretic, diuretic, parasiticide, stimulant and used as a tonic. Hence, the present study is aimed to assess the AM fungal diversity in medicinally important Smilax perfoliata Lour. This is the first report of AM fungal diversity of this medicinally important plant.

\section{Materials and Methods}

\section{Sampling site and collection of soil and root samples}

The sampling site was located in Manas National Park, Assam in India. The study site was located in the Himalayan foothills, it is contiguous with the Royal Manas National Park in Bhutan. The geographical coordinates of the study sites are $26^{\circ} 43{ }^{\prime} \mathrm{N}$ and $90^{\circ} 56^{\prime} \mathrm{E}$. Smilax perfoliata Lour, a medicinally important plant was selected for the present investigation (Photo plate 1). Rhizospheric soil samples of the selected plant Smilax perfoliata Lour were asceptically collected from a depth of $<20 \mathrm{~cm}$ using V-shaped technique (Bashan and Wolowelsky, 1987). 
The fine roots of the plant were also collected during the sampling. Sampling was carried out in triplicates. The soil and root samples of a single plant were collected separately in polypropylene bags and transported to the laboratory on the same day of collection. Samples were kept at $4{ }^{0} \mathrm{C}$ in the laboratory for further analysis.

\section{Soil physicochemical characteristics}

Fresh air dried soil samples were used for physicochemical analysis. Soil $\mathrm{pH}$ was determined using electronic digital $\mathrm{pH}$ meter (eco Testr pH1) in soil/water suspension, 1:5, w/v. Soil moisture content (MC) was determined as used by Tapadar and Jha (2016a). Walky and Black's (1934) titrimetric chromic acid wet oxidation method was used for the determination of soil organic carbon $\left(\mathrm{C}_{\text {org }}\right)$ content. Bray's method (1945) was adopted for the determination of available phosphorus $(\mathrm{P})$ concentration, while available nitrogen $(\mathrm{N})$ concentration was estimated by the alkaline potassium permanganate method of Subbiah and Asija (1956). Potassium (K) concentration was estimated using flame photometric method (Toth and Prince, 1949).

\section{AM fungal root colonization}

AM fungal root colonization of fine roots were assessed by following the method of Kormanik and McGraw (1982). Roots of 1 $\mathrm{cm}$ length were mixed with $\mathrm{KOH}(10 \%)$ and autoclaved at $15 \mathrm{lb}$ inch $^{-2}$ pressure for 5 minutes. The coloured root segments were bleached with freshly prepared alkaline $\mathrm{H}_{2} \mathrm{O}_{2}$ and were acidified with $1 \% \mathrm{HCl}$. The acidified root segments were stained with $0.05 \%$ (W/V) tryphan blue. The stained roots were destained in lactic acid and mounted on a slide using lactophenol and examined under light microscope. The root colonization (RC) percentage was calculated by following the formula: $\mathrm{RC}(\%)=$ (total no. of colonized root segments/total no. of examined root segments) $\times 100$.

\section{AM fungal spore isolation}

Spores of arbuscular mycorrhizal fungi were extracted from soil samples using slightly modified combination of wet sieving and decanting method (Gerdemann and Nicolson, 1963).

Twenty gram air-dried soil was suspended in $1000 \mathrm{ml}$ of water and shaken for $10 \mathrm{mins}$ and kept undisturbed for $1 \mathrm{~h}$ in order to allow heavier particles to settle down. The soil suspension was decanted through a series of sieves of different sizes i.e. $250 \mu \mathrm{m}\left(1^{\mathrm{st}}\right), 125$ $\mu \mathrm{m}\left(2^{\text {nd }}\right), 60 \mu \mathrm{m}\left(3^{\text {rd }}\right)$ and $37 \mu \mathrm{m}\left(4^{\text {th }}\right)$.

The seivings retained on the $2^{\text {nd }}, 3^{\text {rd }}$ and $4^{\text {th }}$ sieves were suspended in minimal amount of water and filtered using filter paper. Filter papers were transferred to petridishes and spores were counted and sorted based on their size, shape, and colour under stereomicroscope (Labomed CZM4 model; $10 \mathrm{X} \times 4 \mathrm{X})$ using bamboo needle (15 cm long).

The morphologically identical spores were used together (20-25 nos.) for preparation of diagnostic slide using polyvinyl-lactoglycerol (PVLG) or PVLG+Melzer's reagent (1:1 ratio) as mountants and observed under compound microscope (Labomed ATC2000 model;10X $\times 40 \mathrm{X}$ magnification) using the method of Schenck and Perez (1990).

Identification of AM spores were done based on size, shape, colour, wall structure, surface ornamentation, hyphal attachments and presence or absence of bulbous suspensor using online species descriptions of INVAM (International Culture Collection of Vesicular-Arbuscular Mycorrhizal Fungi; http://invam.caf.wvu.edu), http://www.amfphylogeny.com, http://indexfungorum.org and published original species descriptions. 


\section{Trap culture}

Trap cultures were established from fresh soil samples to isolate more spores. Allium cepa and Zea mays were used alternatively as trap plants. The experiment was conducted under normal conditions. The root colonization and spore density were studied after 2 month of establishment of trap culture.

\section{Monosporic culture of AMF}

For establishment of monosporic culture, soil and sand in 1:1 ratio was sterilized twice separately with a time gap of $24 \mathrm{~h}$ in polypropylene bags at $15 \mathrm{lb}$ inch $^{-2}$ pressure for $20 \mathrm{~min}$. Five maize seeds were allowed to germinate in a medium sized plastic pot filled with sterilized soil and sand (1:1) mixture. After germination seedlings were thinned to 3 per pot. The roots of maize seedling were inoculated with a healthy single spore. Establishment of root infection was confirmed after 30 days by examining root pieces for colonization. Upon confirmation, successful cultures (soil and sand mixture with root pieces) were transferred to big pots $(2.5 \mathrm{Kg})$. The spores of each isolate were identified and maintained for further investigation.

\section{Statistical analysis}

Relative abundance (RA) of AM fungal species was studied as described by Dandan and Zhiwei (2007).

\section{Results and Discussion}

\section{Phycochemical properties of soil}

The examined physicochemical properties were $\mathrm{pH}$, moisture content (MC), $\mathrm{C}_{\text {org }}(\%)$, Av. $\mathrm{N}_{2}(\mathrm{Kg} / \mathrm{ha})$, Av. $\mathrm{P}_{2} \mathrm{O}_{5}(\mathrm{Kg} / \mathrm{ha})$ and Av. $\mathrm{K}_{2} \mathrm{O}(\mathrm{Kg} / \mathrm{ha})$. The studied soil sample was found to be slightly alkaline with $\mathrm{p}^{\mathrm{H}}$ 7.8. The $\mathrm{C}_{\text {org }}$ concentration was found high $(4.07 \%)$.
The available concentration of NPK were $1354.15(\mathrm{Kg} / \mathrm{ha}), 106.44(\mathrm{Kg} / \mathrm{ha})$ and 356.16 $(\mathrm{Kg} / \mathrm{ha})$ respectively for nitrogen, phosphorus and potassium.

\section{AM fungal root colonization}

The roots of Smilax perfoliata Lour were colonized by AM fungi. The colonization in the form of arbuscles, vesicles, hyphae and hyphal coils were observed during the investigation. The percent root colonization was recorded $82.98 \pm 1.01 \%$. The percentage of hyphae, vesicle and arbuscule structures observed in colonized roots were respectively $29.9 \%, 52.06 \%$ and $18.04 \%$.

\section{AM fungal spore density and composition}

AM Fungal spore density in the soil sample of Smilax perfoliata Lour was recorded 147 spores $20 \mathrm{gm}^{-1}$. A total 23 AM fungal taxa were identified based on their morphological characteristics (Table 1). Some spores could not be identified due to lack of proper spore structures and low number.

Among the identified taxa, 16 (69.57\%) were identified at the species level, while the remaining $7(30.43 \%)$ were identified at the generic level. Out of the 23 identified AM fungal taxa, 16 belonged to Glomeraceae, 3 belonged to Acaulosporaceae, 2 belonged to Gigasporaceae and 2 belonged to Claroideoglomeraceae. Three generic taxa (Funneliformis, Glomus, Rhizophagus) were identified within Glomeraceae; 1 generic taxa identified each within Acaulosporaceae (Acaulospora), Gigasporaceae (Scutellospora) and Claroideoglomeraceae (Claroideoglomus). Rhizophagus fasciculatus and Glomus citricola showed highest relative abundance $(6.45 \%)$ followed by Glomus aureum, Rhizophagus clarus and Glomus aggregatum (5.79\%), Funneliformis badium, F. caledonium (5.11\%), G. sp.3 (5.01\%), 
Claroideoglomus etunicatum, F. geosporum, C. claroideum, G. sp.1, Acaulospora scrobiculata (4.43\%), G. multicaule, $G$. reticulatum, G. hoi, $R$. intraradices, $G$. sp. 2 (3.75\%), G. canadense, A. sp.1, A. sp.2, Scutellospora sp.2 (3.07\%) and $S . \quad$ sp.1 (2.39\%) (Fig. 1).

\section{Trap culture}

The percentage of AM fungal root colonization was recorded 52\% and 56\% respectively in maize and onion trap plant. The root colonization of onion plants was more as compared to roots of maize plants. The AM fungal spore density in soil of trap culture was found 45 spore $20 \mathrm{gm}^{-1}$ soil. Eighteen AM fungal taxa were recorded from trap culture (Table 2). Glomus citricola showed highest relative abundance (12.84\%) followed by Rhizophagus fasiculatus (10.62\%), Acaulospora scrobiculata, Funneliformis geosporum, Glomus aggregatum (8.39\%), Ambispora jimgerdemannii and G. pellucidum (7.28\%), Acaulospora denticulata (6.17\%), A. sp.1, G. sp.4 and G. aureum (5.06\%), G. badium, G. tortuosum and Gigaspora rosea (3.95\%), $R$. diaphanum, Sclerocystis sp. and Scutellospora sp.1 (2.84\%). Nine AM fungal taxa viz. Acaulospora gerdemanni, A. denticulata, Glomus sp.4, G. pellucidum, G. tortuosum, Rhizophagus diaphanum, Ambispora fecundispora, A. jimgerdemannii, Gigaspora rosea and Sclerocystis sp.1 were recorded in trap culture that was not observed in original soil sample.

\section{Monosporic culture}

There were five monosporic culture of AM fungi successfully developed. Root colonization test was also carried out for confirmation of the success of root infection. Subsequently, spores of monosporic culture were extracted and verified. The results of monosporic culture are presented in table 3. The monocultures of Rhizophagus fasciculatus, Glomus agregatum, $G$. citricola, Funneliformis geosporum and Claroideoglomus etunicatum were successfully raised. The root colonization and spore density were highest in case of $F$. geosporum and lowest in case of $C$. etunicatum.

Plate.1 Smilax perfoliata Lour. Plant

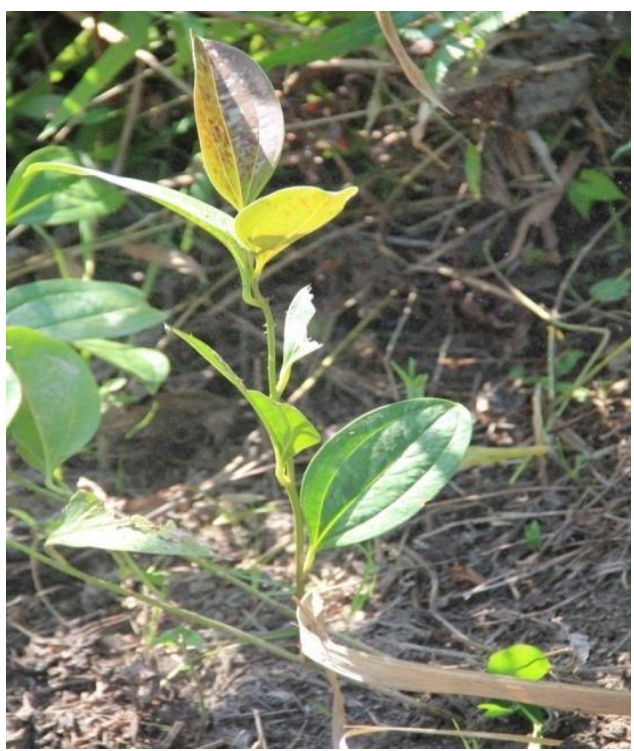


Plate.2 AM fungal morphotypes isolated from the rhizospheric soils of Smilax perfoliata Lour. (a: Rhizophagus fasciculatus; b: Glomus citricola; c: G. hoi; d: G. geosporum; e: Glomus sp.; f:

Sclerocystis sp.; g: Funneliformis badium; h: G. reticulatum; i: Glomus sp.)
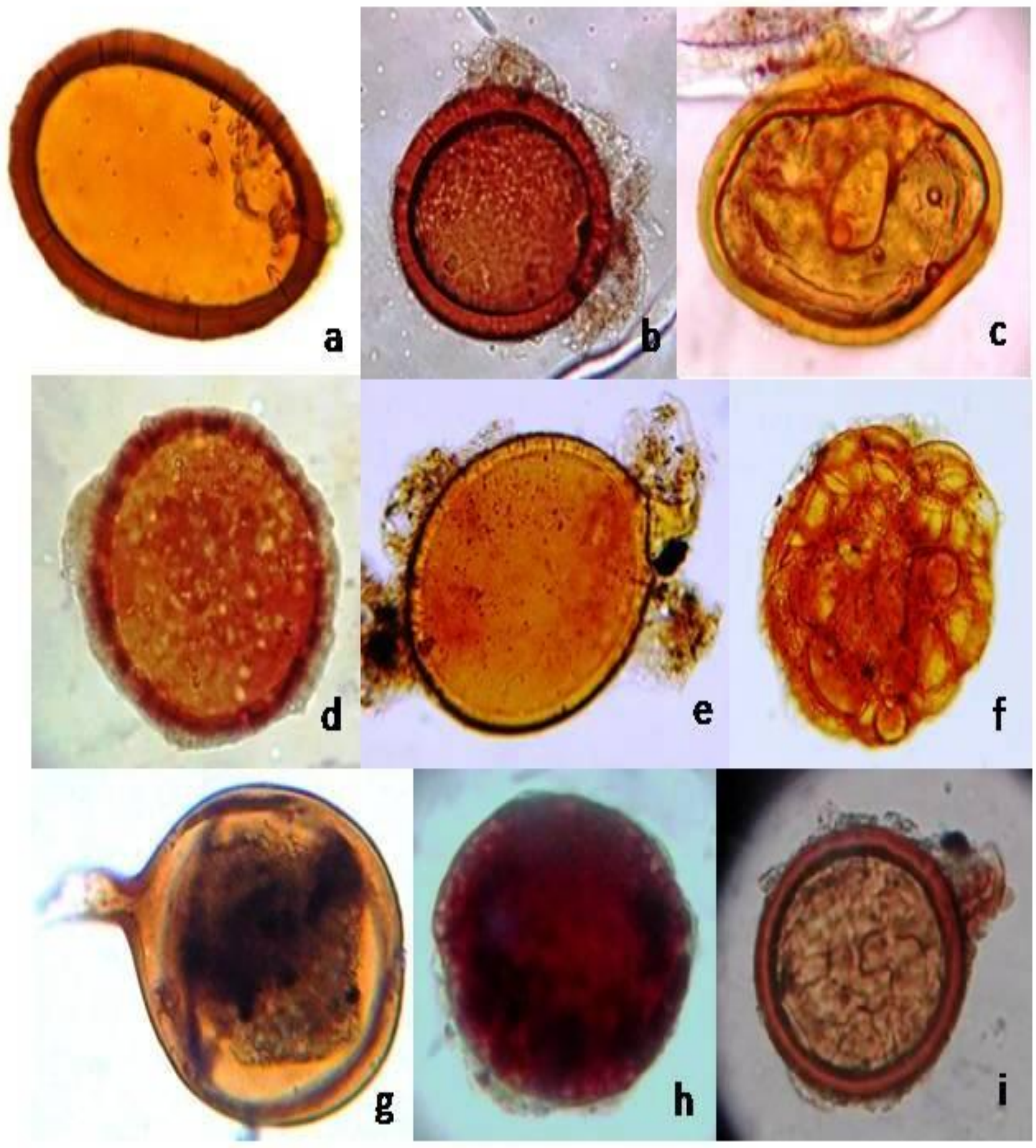
Table.1 AM fungal composition in Smilax perfoliata Lour.

\begin{tabular}{lc}
\hline AM Fungal Taxa & Relative abundance (\%) \\
\hline Funneliformis badium Oehl, D. Redecker \& Sieverd. & 5.11 \\
F. geosporum C.Walker & 4.43 \\
F. caledonium (T.H. Nicolson \& Gerd.) Trappe \& Gerd. & 5.11 \\
Glomus aureum Oehl \& Sieverd & 5.79 \\
G. multicaule Gerd.\& B.K. Bakshi & 3.75 \\
G. reticulatum & 3.75 \\
G. aggregatum N.C. Schenck \& G.S. Sm. & 5.79 \\
G. citricola D.Z. Tang \& M. Zang & 6.45 \\
G. hoi S.M. Berch \& Trappe & 3.75 \\
G. canadense (Thaxt.) Trappe \& Gerd. & 3.07 \\
G. sp.1 & 4.43 \\
G. sp.2 & 3.75 \\
G. sp.3 & 5.01 \\
Rhizophagus fasciculatus (Thaxt.) Gerd. \& Trappe & 6.45 \\
R. intraradices N.C.Schenck \& G.S. Sm. & 3.75 \\
R. clarus T.H. Nicolson \& N.C. Schenck & 5.79 \\
Claroideoglomus etunicatum W.N. Becker \& Gerd. & 4.43 \\
C. claroideum D.D. Mill. \& C. Walker & 4.43 \\
Acaulospora scrobiculata Trappe & 4.43 \\
A. sp.1 & 3.07 \\
A. sp.2 & 3.07 \\
Scutellospora sp.1 & 2.39 \\
S. sp.2 & 3.07 \\
\hline
\end{tabular}

Table.2 AM fungal composition in trap culture

\begin{tabular}{lc}
\hline AMF & Relative abundance (\%) \\
\hline Funneliformis geosporum C.Walker & 8.39 \\
F. badium Oehl, Redecker \& Sieverd & 3.95 \\
Glomus citricola D.Z. Tang \& M. Zang & 12.84 \\
G. aggregatum N.C. Schenck \& G.S. SM & 8.39 \\
G. aureum Oehl \& Sieverd & 5.06 \\
G. pellucidum Mc Gee \& Pattinson & 7.28 \\
G. tortuosum N.C. Schenck \& G.S. Sm. & 3.95 \\
G. sp.4 & 5.06 \\
Rhizophagus fasiculatus Gerd \& Trappe & 10.62 \\
R. diaphanum J.B. Morton \& C. Walker & 2.84 \\
Sclerocystis sp. 1 & 2.84 \\
Gigaspora rosea T.H. Nicolson \& N.C. Schenck & 3.95 \\
Scutellospora sp.1 & 2.84 \\
Acaulospora scrobiculata Trappe & 8.39 \\
A. denticulata Sieverd. \& S. Toro & 6.17 \\
A. sp.1 & 5.06 \\
Ambispora fecundispora N.C. Schenck \& G.S. Sm. & 6.17 \\
A. jimgerdemannii N.C. Schenck\& T.H. Nicolson & 7.28 \\
\hline
\end{tabular}


Table.3 Root colonization (\%) and Diversity measurement of AM Fungi community in monoculture of AM Fungi

\begin{tabular}{lcc}
\hline \multicolumn{1}{c}{ AM Fungi } & $\begin{array}{c}\text { Root } \\
\text { colonization (\%) }\end{array}$ & $\begin{array}{c}\text { Spore density } \\
\left(\mathbf{5 0 g m} \mathbf{g m}^{-1}\right)\end{array}$ \\
\hline Rhizophagus fasciculatus (Thaxt.) Gerd. \& Trappe & 46 & 80 \\
Glomus aggregatum N.C. Schenck \& G.S. SM & 59 & 75 \\
Glomus citricola D.Z. Tang \& M. Zang & 59 & 75 \\
Funneliformis geosporum C.Walker & 62 & 85 \\
Claroideoglomus etunicatum W.N. Becker \& Gerd & 40 & 40 \\
\hline
\end{tabular}

The present study provided the status of AM fungal diversity in Smilax perfoliata Lour. The AM fungal population and diversity status in the soil is dependent on the factors viz. climate, soil physicochemical properties and the host plant (Hayman 1982; Brundett 2009; Dehne et al.,1987). It was reported that abiotic factors are more important (Panwar and Tarafdar 2006) in the distribution of AM fungi. The physicochemical results of studied soil sample indicated that the soil was alkaline (pH 7.8). Alkalinity of soils is primarily caused due to the presence of soil minerals producing carbonate upon weathering (Wang et al., 2015). It was reported that the soil moisture influenced the AM fungal root colonization (Lingfei et al., 2005). Jha et al., (1992) reported positive correlation between AM fungal root colonization and soil moisture. The root colonization percentage and AM fungal spore density of Smilax perfoliata Lour plant was high suggesting high degree of infection. Total 23 different AM fungal taxa were found from the soil sample. In trap culture, total 18 AM fungal taxa were isolated. In trap culture, additional species were isolated viz. Acaulospora denticulata, Glomus nigrum, G. pellucidum, G. tortuosum, Rhizophagus diaphanum, Ambispora fecundispora, A. jimgerdemannii, Gigaspora rosea and Sclerocystis sp.1 that were not recorded from field soil sample of Smilax perfoliata Lour.

Glomus was the dominant genus during the present investigation. It was isolated in more numbers as compared to the other genus in both field and trap soil samples of Smilax perfoliata Lour. It was reported that the Glomus is the dominant genus of various natural ecosystems (Li et al., 2009; Muthukumar and Udaiyan 2000; Zhao et al., 2001; Guaderramma and Alveraz-Sanchez 1999; Hijri et al., 2006). Species of the genus Glomus has more tolerant to various disturbances and agricultural practices. Singh et al., (2008) observed strong dominance of Glomus and moderate numbers of Acaulospora, Gigaspora and Scutellospora in cultivated and natural tea bushes. It was reported also that various disturbance alter species composition of AM fungi, including loss of large-spored Gigasporaceae and an increase in smaller Glomus species (Johnson, 1993).

Five monocultures of Rhizophagus fasciculatus, Glomus aggregatum, Glomus citricola, Funneliformis geosporum and Claroideoglomus etunicatum were successfully developed. These monosporic culures of AMF can be used in applied field.

Thus, further studies should focus on establishment monoculture of these AM fungal species, which have a significant use as inoculants for nursery seedlings and trees of the region. The present investigation provides knowledge and understanding about the presence and diversity of AMF in Smilax perfoliata Lour. and good possibilities for further studies and utilization of AM fungi. 


\section{Acknowledgements}

The authors acknowledge the authorities of Manas National Park, Assam, India for permission and cooperation during collection of samples.

\section{References}

Bedini, S., Pellegrino, E., Avio, L., Pellegrini, S., Bazzoffi, P., Argese, E. and Giovannetti, M. 2009. Changes in soil aggregation and glomalin-related soil protein content as affected by the arbuscular mycorrhizal fungal species Glomus mosseae and Glomus intraradices. Soil Biology and Biochemistry. 41:1491-1496.

Bona, E., Manassero, P., Marsano, F., Todeschini, V., Cantamessa, S., Copetta, A., D'Agostino, G., Gamalero, E. and Berta, G. 2013. Arbuscular Mycorrhizal Fungi and Plant Growth-Promoting Pseudomonads Increases Anthocyanin Concentration in Strawberry Fruits in Conditions of Reduced Fertilization. International Journal of Molecular Sciences. 14: 16207-16225.

Bray, R.H. and Kurtz, L.T. 1945. Determination of total, organic and available forms of phosphorus in soils. Soil Science. 59: 3946.

Brundrett, M. 2009. Mycorrhizal associations and other means of nutrition of vascular plants: understanding the global diversity of host plants by resolving conflicting information and developing reliable means of diagnosis. Plant and Soil 320: $37-77$.

Buragohain, J. 2011. Ethnomedicinal plants used by ethnic communities of Tinsukia District of Assam, India. Recent Research in Science and Technology. 3(9), 31-42.

Dandan, Z. and Zhiwei Z. 2007. Biodiversity of arbuscular mycorrhizal fungi in the hot dry valley of the Jinsha River, southwest China. Applied Soil Ecology 37:118-128.

Dehne, H.W. 1987. Management of VA mycorrhizae in temperate crops. In:
Mycorrhizae in the next decade-practical applications and research pririties. Proc. 7th North American Conf. On Mycorrhizae, Gainesville, FL. 3-8 May. Univ. Of Florida, Gainesville, FL.

Gerdemann, J.W. and Nicolson, T.H. 1963. Spore of mycorrhizal Endogone species extracted from soil by wet-sieving and decanting method. Transactions of the British Mycological Society. 46: 235-244.

Gianinazzi-Pearson, V., Dumas-Gaudot, E., Gollotte, A., Tahiri-Alaoui, A. and Gianinazzi, S. 1996. Cellular and molecular defencerelated root responses to invasion by arbuscular mycorrhizal fungi. New Phytologist. 133: 45-57.

Grime, J.P., Mackey, J.M.L., Hillier, S.H. and Read, D.J. 1987. Floristic diversity in a model system using experimental microcosms. Nature. 328: 420-422.

Guadarrama, P. and Álvarez-Sánchez, F.J. 1999. Abundance of arbuscular mycorrhizal fungi spores in different environments in a tropical rain forest, Veracruz, Mexico. Mycorrhiza 8: 267270.

Hayman, D.S. 1982. Influence of soils and fertility on activity and survival of VAM fungi. Phytopathology. 72: 1119-1125.

Hijri, I., Sýkorová, Z., Oehl, F., Ineichen, K., Mäder, P., Wiemken, A. and Redecker, D. 2006. Communities of arbuscular mycorrhizal fungi in arable soils are not necessarily low in diversity. Molecular Ecology. 15: 2277-2289.

Jha, D.K., Sharma, G.D. and Mishra, R.R. 1992. Ecology of soil microflora and mycorrhizal symbiosis in degraded forests at two altitudes. Biology and Fertility of Soils. 12(4): 271-278.

Johnson, N.C. 1993. Can fertilization of soil select less matualistic mycorrhizae? Ecological Applications.3(4): 749-757.

Jordan, N. And Huerd, S. 2008. Effects of Soil Fungi on Weed Communities in a Cornsoybean Rotation. Renewable Agriculture and Food Systems. 23:108-117.

Kormanik, P.P. and McGraw, A.C. 1982. Quantification of Vesicular-arbuscular 
Mycorrhizae in Plant Roots. In Schenck, N.C. (Ed) Method and Principles of Mycorrhizal Research. The Plant American Phytopathological Society. p. 37.

Li, L.F., Yang, A.N. and Zhao, Z.W. 2005. Seasonality of arbuscular mycorrhizal symbiosis and dark septate endophytes in a grassland site in southwest China. FEMS Microbiology Ecology. 54: 367373.

Li, R., Guan, K-Y., Stonor, R., Smith, S.E. and Smith, F.A. 2013. Direct and indirect influences of arbuscular mycorrhizal fungi on phosphorus uptake by two root hemiparasitic Pedicularis species: do the fungal partners matter at low colonization levels? Annals of Botany. 112: 10891098.

Likar, J.J., Bogorad, A.L., Lombardi, R.E., Herschitz, R., Pitchford, D., Kircher, G. and Mandell, M.J. 2009. Spacecraft Charging Monitoring at GEO: Natural and Electric Propulsion Environment Measurements, 47th AIAA Aerospace Sciences Meeting Including The New Horizons Forum and Aerospace Exposition 5 - 8 January, Orlando, Florida.

Likar, M., Bukovnik, U., Kreft, I., Chrungoo, N.K. and Regvar, M. 2008. Mycorrhizal status and diversity of fungal endophytes in roots of common buckwheat (Fagopyrum esculentum) and tartary buckwheat tataricum). Mycorrhiza. 18: 309-315.

Lingfei, L., Anna,Y. and Zhiwei, Z. 2005. Seasonality of arbuscular mycorrhizal symbiosis and dark septate endophytes in a grassland site in southwest China. FEMS Microbiol Ecology. 54: 367-373.

Molecular diversity of arbuscular mycorrhizal fungi and their distribution patterns related to host-plants and habitats in a hot and arid ecosystem, southwest China Ling-Fei Li1,2, Tao Li2, Yan Zhang2 \& Zhi-Wei Zhao2, Received 1 May 2009; revised 6 November 2009; accepted 8 November 2009. Final version published online $\quad 15 \quad$ December 2009. DOI:10.1111/j.1574-6941.2009.00815.x, FEMS Microbiol Ecol 71 (2010) 418427.

Muthukumar, T. And Udaiyan, K. 2000. Arbuscular mycorrhizas of plants growing in the Western Ghats region, Southern India. Mycorrhiza. 9: 297-313.

Muthukumar, T. and Udaiyan. K. 2000. Arbuscular mycorrhizas of plants growing in the Western Ghats region, Southern India. Mycorrhiza. 9: 297-313.

Panwar, J. and Tarafdar, J.C. 2006. Distribution of three endangered medicinal plant species and their colonization with arbuscular fungi. Journal of Arid Environments. 65:337-350.

Pawer, R.K., Sharma, S., Singh, K.C. and Sharma, R.K.R. 2011. Physicochemical standardisation and development of HPTLC method for the determination of Plumbagin in Kalmegh Navayas Loha an ayurvedic formulation. International Journal of Current Pharmaceutical Research. 3(1): 30-34.

Rani, V. and Bhaduria, S. 2001. Vesicular Arbuseular mycorrhizal association on some medicinal plants growing on alkaline soils of Manipur district. Uttara Pradesh. Mycorrhiza News. 13(2): 12-14.

Schenck, N.C. and Perez, Y. 1990 Manual for the identification of VA-mycorrhizal fungi. 3rd edition: Gainesville, Fl: Synergistic Publications. Vol. 1 \& 2 .

Schüßler, A., Schwarzott, D. and Walker, C. 2001. A new fungal phylum, the Glomeromycota: phylogeny and evolution. Mycological Research. 105(12):1413-1421.

Selvoraj, T.R., Murugan and Bhaskaran, C. 2001. Arbuscular mycorrhizal association of kashini (Cichorium intybus L.) in relation to Physicochemical characters. Mycorrhiza News., 13 (2):14-16.

Singh, $\quad$ B.K., Nunan, N., Ridgway, K.P., McNicol, J., Young, J.W.P., Daniell, T.J., Prosser, J.I., Millard, P. 2008. Relationship between assemblages of mycorrhizal fungi and 
bacteria on grass roots. Environmental Microbiology 10: 534-541.

Smith, S.E. and Read, D.J. 1997. Mycorrhizal symbiosis, Academic Press, Inc San Diego California.

Smith, S.E. and Read, D.J. 2008. Mineral nutrition, toxic element accumulation and water relations of arbuscular mycorrhizal plants. In: Smith, S. E., and Read, D. J. Mycorrhizal Symbiosis. Academic Press, London. 3: 145-18.

Stein, C., Rißmann, C., Hempel, S., Renker, C., Buscot, F., Prati, D. and Auge, H. 2009. Interactive effects of mycorrhizae and a hemiparasite on plant community productivity and diversity. Oecologia. doi:10.1007/ s00442-008-1192-x

Subbiah, B. and Asija, G.L. 1956 A rapid procedure for estimation of available nitrogen in soils. Current Science 25: 259260.

Tapadar, S.A. and Jha, D.K. 2016a. Seasonal and Temporal Dynamics of Physicochemical and Biological Properties of Chronosequence Coal Mine Spoil Soils. CLEAN. 44(9999):1-9.

Tapadar, S.A., Kamchi, T., Hussain, A. and Jha, D.K. 2016b. Association of the Arbuscular Mycorrhizal Fungi with Cinnamomum tamala (Buch.-Ham.) T. Nees \& Eberm. Research Journal of Contemporary Research. 10 \& 11 (B): 127-138.

Toth, S.J. and Prince, A.L. 1949. Estimation of cation exchange capacity and exchangeable calcium, potassium, and sodium contents of soil by flame photometer techniques. Soil Science. 67: 439-445.

van der Heijden, M.G.A. and Horton, T.R. 2009. Socialism in soil? The importance of mycorrhizal fungal networks for facilitation in natural ecosystems. Journal of Ecology. 97: 1139-1150.

Van der Heijden, M.G.A., Bardgett, R.D., Van Straalen, N.M. 2008. The unseen majority: Soil microbes as drivers of plant diversity and productivity in terrestrial ecosystems. Ecology Letters 11: 296-310.

Walkley. A. and Black, I.A. 1934. An examination of the Degtjareff method for determining soil organic matter, and proposed modification of the chromic acid titration method. Soil Science 37: 29-37.

Wang, C., Li, W., Yang, Z., Chen, Y., Shao, W., and Ji, J. 2015. An invisible soil acidification: Critical role of soil carbonate and its impact on heavy metal bioavailability. Scientific Reports. 5:12735

Zhao, Z.W., Xia, Y.M., Qin, X.Z., Li, X.W., Cheng, L.Z., Sha, T. and Wang, G.H. 2001. Arbuscular mycorrhizal status of plants and the spore density of arbuscular mycorrhizal fungi in the tropical rain forest of Xishuangbanna, southwest China. Mycorrhiza 11: 159- 162.

Zhasa, N.N., Hazarika, P. and Tripathi, Y.C. 2015. Indigenous Knowledge on Utilization of plant Biodiversity for Treatment and Cure of diseases of Human beings in Nagaland, India: A case study. International Research Journal of Biological Sciences. 4(4): 89-106.

\section{How to cite this article:}

Sufian A. Tapadar, Himadri Kalita, Afrida Hussain, Daimalu Baro and Jha, D.K. 2017. Diversity of Arbuscular Mycorrhizal Fungi Associated with Smilax perfoliata Lour. Int.J.Curr.Microbiol.App.Sci. 6(7): 4501-4511. doi: https://doi.org/10.20546/ijcmas.2017.607.469 